\title{
Drivers of International Migration in Zimbabwe
}

\author{
Nyamuranga Farai $\mathrm{J}^{1^{*}} \quad$ Mabonga Joshua $\mathrm{T}^{2}$ \\ 1.History and developmental studies, Midlands State University P. Bag 9055, Senga, Gweru, Zimbabwe \\ 2.Faculty of Commerce, Banking and Finance department, Midlands State University P. Bag 9055, Senga, \\ Gweru, Zimbabwe
}

\begin{abstract}
This paper sought to establish the major drivers of international migration by Zimbabwe citizens, emphasising on different reasons which stimulate most citizens to move to different parts of the world. Qualitative data was captured through desktop research, interviews and Focused Group Discussions with immigrants already in the diaspora and those that were actively seeking avenues to leave the country through application of visas and conducting of interviews with respective embassies. The paper reviews that the major drivers of international migration from Zimbabwe are divided into four groups namely predisposing factors, proximate factors, precipitating factors and mediating factors coupled with the social, economic, political, religious and environmental circumstances bedevilling the country. on.
\end{abstract}

Keywords: international migration, diaspora, focused group discussions.

DOI: $10.7176 /$ RHSS/10-24-11

Publication date: December $31^{\text {st }} 2020$

\section{Introduction}

Zimbabwe has been facing a wide range of challenges since the early 1990s to date. This has seen hundreds of Zimbabweans migrating to different parts of the world, particularly U.K, U.S.A, Australia, Ireland, and Canada and even nearby countries such as South Africa, Botswana and Namibia. Historically, Zimbabwe was known as a sender and receiver of migrants. The end of colonialism in 1980 saw a large number of the white Zimbabwean population leaving the country going back to Europe, especially Britain. It also saw a large number of people immigrating from other countries, especially in Africa because then, Zimbabwe had arguably the best economy and currency on the African continent and it was also arguably the second most developed country after South Africa (Ndlovhu 2008).

Zimbabwe was known to be the 'bread basket' of Africa because it had a well developed agriculture system and had the potential to produce so much food that it exported some to other countries. It also produced its own electricity at Kariba, Hwange and Munyati power stations. This development as well as socio-economic stability was, thus, a key pull factor for migrants from across Africa and also the world as a whole. However, all these favourable conditions have since changed and Zimbabwe's economy and its blooming standards of living have been drifting further and further away from blossom to underdevelopment.

Zimbabwe's steady decline commenced from the early 1990s. From 1991 to 1996, the Zimbabwean ZANU (P.F) government of President Robert Mugabe embarked on an Economic Structural Adjustment Programme (ESAP), which was designed by the IMF and the World Bank. This programme had serious negative effects on the economy of Zimbabwe. According to Latham (2010), in the late 1990s the government also instituted land reforms which were intended to remove white landowners and put their holdings in the hands of black farmers. However, a lot of these "farmers" had no experience or training in farming. According to Coltart (2008), from 1999 to 2009, the country then experienced a drop in food production and also in all other sectors. The banking sector collapsed as well and farmers were unable to obtain loans to assist them for capital development. Food output capacity also fell by $45 \%$ and manufacturing output fell by $29 \%$ in 2005 , by $26 \%$ in 2006 and by $28 \%$ in 2007. Unemployment also rose to $80 \%$ (ibid). Life expectancy also dropped. According to Kant (2008), this economic downturn can also be attributed to the farm invasions in 2000. White commercial farmers, on whose farming Zimbabwe was dependent, were either violently forced to leave or decided to leave because of the violence and lawlessness which characterized the land reform programme. This, together with the other factors noted above, saw a marked decline in agricultural production, which also saw a huge decline in the value of the Zimbabwean dollar never seen on this earth in history (Kant 2008).

Zanamwe and Dellivard (2009) further highlight that economically; Zimbabwe has not been performing well from 2000. The country's Gross Domestic Product (GDP) declined by 46 per cent between 2000 and 2007. The unstable macroeconomic environment was characterized by hyperinflation, with annual inflation reaching 231 million per cent in July 2008. The economy then experienced severe shortages of basic commodities, including drugs, food, fuel, and industrial and consumer goods. The past decade also witnessed increasing poverty levels; for example, the Total Consumption Poverty Line (TCPL) rose from 61 per cent in 1995 to 72 per cent in 2003 (Zanamwe and Dellivard 2009). This has, thus, continued to be a push factor for Zimbabweans to migrate to other parts of the world. 
The net migration in Zimbabwe was last measured at 400000 in 2012, (The World Bank 2012). Data to calculate these official estimates come from different sources which include border statistics, administrative records, surveys, and censuses. When no official estimates can be made because of insufficient data, net migration is derived through the balance equation, which is the difference between overall population growth and the natural increase during the 1990-2000 intercensal periods. Hence, this is the latest recorded value on historical data chart and related indicators for net migration in Zimbabwe (The World Bank 2012).

Zimbabwe, therefore experienced an increasing rise in emigration since 2000, and the vast majority of the emigrants were to the Southern African region. Emigration patterns have been complex and marked by an increase in informal cross border movement, migration of highly skilled nationals and also survival migration of the poor and the impoverished. Zanamwe and Dellivard (2009) argue that there were 11,620 emigrants in 2005 mainly going to other African countries. In post-2000, Zimbabwe witnessed a sizeable numbers of day trippers going mainly to South Africa and Botswana (ibid). The number of day trippers also increased from 651,703 in 2005 to 629,387 in 2006 . The figure declined to 431,951 in 2007 . In 2008, a total of 71 foreign nationals were deported from Zimbabwe, while 114,848 Zimbabwean nationals were repatriated to the country from other countries (ibid). Host countries such as Botswana, Zambia, South Africa, Namibia and even Britain and Australia have immensely benefited from the exodus of Zimbabweans into their countries. These countries enjoy benefits of cheap labour as many of the migrants take up blue collar jobs such as driving, working in farms, cleaning the streets as well as other low key job. South Africa has been noted to be the main recipient of these Zimbabwean migrants. It is estimated that about 5 million Zimbabweans live in South Africa alone (Kant 2008).

There is no doubt that the economic condition in Zimbabwe still continues to be the major factor facilitating for the emigration of highly skilled as well as low-skilled nationals. In the last 10 years or so, Zimbabwe has witnessed unprecedented flows of emigration in her history to other countries across the globe in search of greener pastures. It is estimated that there are millions of Zimbabwean resident outside the country (Tevera and Zinyama 2002). Many recent emigrants are illegally residing in other countries because of the fall of the standard of living and economic conditions in Zimbabwe. Destinations for most of these emigrants are Australia, U.S.A, United Kingdom, South Africa, Botswana and Canada (ibid). According to Ezra (2009), in Australia, Zimbabwean emigrants were estimated to be over 30,000 as of 2011. In Botswana, they were estimated to be between forty and one hundred thousand Zimbabweans as of 2009 (ibid). Jonathan et al (2003) estimates that in Canada, the Zimbabwean community has been slowly but steadily increasing since 2000. In South Africa, they are estimated to be between one and five million Zimbabweans as of 2008 (Kant 2008). The UK Zimbabwean community is said to be close to 100,000 (Tara 2008). Steffes (2005) estimated that in America there were 100,000 Zimbabweans in 2000 in the state of New York alone and in Chicago there were perhaps 80 to 100 people.

A lot of qualified personnel have also been emigrating from Zimbabwe at a very alarming rate. According to Zanamwe and Dellivard (2009), exact numbers and whereabouts of Zimbabwean health professionals working overseas is unknown. However, the Health Minister noted in 2000 that Zimbabwe was losing an average of 20\% of its health care professionals every year to emigration and that each of the country's five main hospitals was losing 24 senior nurses and three doctors every month. He also claimed that 100 doctors and 18,000 nurses had left since 1998 (ibid). In 2002, in the United Kingdom alone, 2,346 work permits were issued to nurses from Zimbabwe (ibid). Zimbabwe was the UK's fourth largest supplier of overseas nurses, after the Philippines, India and South Africa (ibid). According to Kant (2008), of the 1,459 immigrant African doctors working in South Africa in 2000, 642 were from Zimbabwe. Kant (2008) further highlights that thousands of teachers protested, left public education and migrated to other countries in response to the economic crisis in 2008 . As such, it is not only the doctors, nurses and teachers who have been migrating from Zimbabwe, but also other professionals as well as unqualified Zimbabwean emigrants. It is, therefore, the thrust of this paper to establish the major factors contributing to the mass exodus of Zimbabweans to other countries.

\section{Methodology}

Interviews with Zimbabwean migrants in other countries

This study was conducted through formal interviews with key Zimbabwean informants who live in the diaspora. A sample of 30 key Zimbabwean informants living in different countries abroad was interviewed through snowballing, convenient and judgemental sampling method. The distribution of these informants, which most of them are from South Africa, Botswana and Europe, is as presented in the table below; 
Table 1: Distribution of key informants across countries

\begin{tabular}{|l|c|}
\hline Country & Number of informants \\
\hline South Africa & 8 \\
\hline Botswana & 2 \\
\hline Other African countries (Namibia, Angola and DRC) & 3 \\
\hline Britain and Ireland & 6 \\
\hline German & 3 \\
\hline Canada & 2 \\
\hline Australia & 2 \\
\hline USA & 4 \\
\hline Total & $\mathbf{3 0}$ \\
\hline
\end{tabular}

Source: Raw Data

These 30 identified Zimbabwean migrants in the diaspora were then interviewed through verbal telecommunication and social media platforms, using an interview guide prepared.

Focus Group Discussions were also conducted with people in Zimbabwe who were actively seeking for avenues to join the diaspora. These consisted of visa applicants who were waiting to be interviewed at several embassies to attain visas to migrate to other countries, as well as those who were lodging their applications with the respective embassies. Focus group discussions were carried at the Canadian, U.S, British and South African embassies respectively. The Canadian group had 5 respondents, the U.S group had 7 respondents, the British group had 6 respondents, and the SA group had 8 respondents, to make a total of 26 respondents for FGDs. Through these Focus Group Discussions, the objective was to acquire data on why these people were so eager to get visas to travel abroad. An interview Guide also assisted in these FGDs and data was captured through observation on non-verbal affirmations expressed by participants during the FGDs, notes taking and voice recording.

\section{Results}

Major drivers of international migration from Zimbabwe were divided into four groups which are dominantly predisposing factors, precipitating factors and mediating factors. These were defined and comprehensively discussed.

\subsection{Predisposing factors for migration in Zimbabwe}

Predisposing factors can be defined as those factors contributing to the creation of a situation in which migration is more likely (Van Hear et al 2000). Various examples of predisposing factors include structural differences between places of migrant origin and areas of destination shaped by the macro-political economy. These predisposing factors may be results of processes such as environmental change, globalisation, demographic transformation and urbanisation (Van Hear et al 2000). Economic disparities which may occur between countries sending and receiving migrants may include differences in livelihoods, earnings and living standards shaped by the global political economy and its inequities. Political disparities may mean persecution, the relative prevalence of conflict and other areas of human rights and security, associated with disintegration, trends of nation building and reconstitution in regions of migrants' origin. Environmental differences between sending and receiving countries may include the absence or presence of resources, the fertility of soil, water availability and extent of forest cover. Geographical factors under predisposition factors may include issues such as in per capita expenditure on health and education, differentials in income per capita, the relative level of school enrolments among other factors. These predisposing factors for migration are discussed in detail below.

3.1.1 Regional Economic Inequality

Economic inequality refers to a condition in which there is a huge difference between countries in terms of their economies. Regional economic inequality is, therefore differences in economic conditions within a region, for example within Southern Africa.

According to Black et al (2006), inequality is a major driver of migration in most developing countries. As such, international migration is a big symbol of the inequality which exists around the globe. This may be inequality in terms of wages, labour market opportunities, or lifestyles. Black et al (2006) further point out that millions of workers and their families move each year across borders and continents in a bid to seek to reduce what they see as the gap between their own position and that of people in other, wealthier, places.

In Zimbabwe there have been a large number of workers such as doctors, nurses and teachers, engineers, land surveyors and economists who have been embarking on migration to other countries within Southern Africa as a result of the economic differences between the countries in the region. Zimbabwe has been suffering from an economic meltdown which has resulted in several negative results, chief among this being underpayment of workers.

According to a testimony by Imani Countess on 3 June 2015, “Zimbabwe's economy is in deep decline. This 
has made it very hard for average Zimbabweans to work and live, and leaving them less and less confident in their future. The government consistently fails to address the basic needs of its people. According to economists with the Labour and Economic Development Research Institute of Zimbabwe (LEDRIZ), Zimbabwe's fragile economy is characterized by "high external debt, policy discontent, massive and increasing deindustrialization and in formalization. Most workers earn salaries far below the poverty level, and many workers even in the formal sector go for months without receiving their wages.'

Of the 30 migrants whom I interviewed, 8 of them were based in South Africa and $4(50 \%)$ of these were of the view that they migrated to South Africa in pursuit of better standards of living which could not be attained in Zimbabwe. As far as these 4 respondents were concerned, South Africa is far ahead of Zimbabwe in terms of living standards because South Africa's economy is far much better than Zimbabwe's economy. As such, these respondents migrated to South Africa because they were of the assumption that there was a wide economy inequality between South Africa and Zimbabwe.

Figure 1: Economic inequalities between Zimbabwe, Zambia, Mozambique, Botswana and South Africa GOP per capita (current). \% of world average

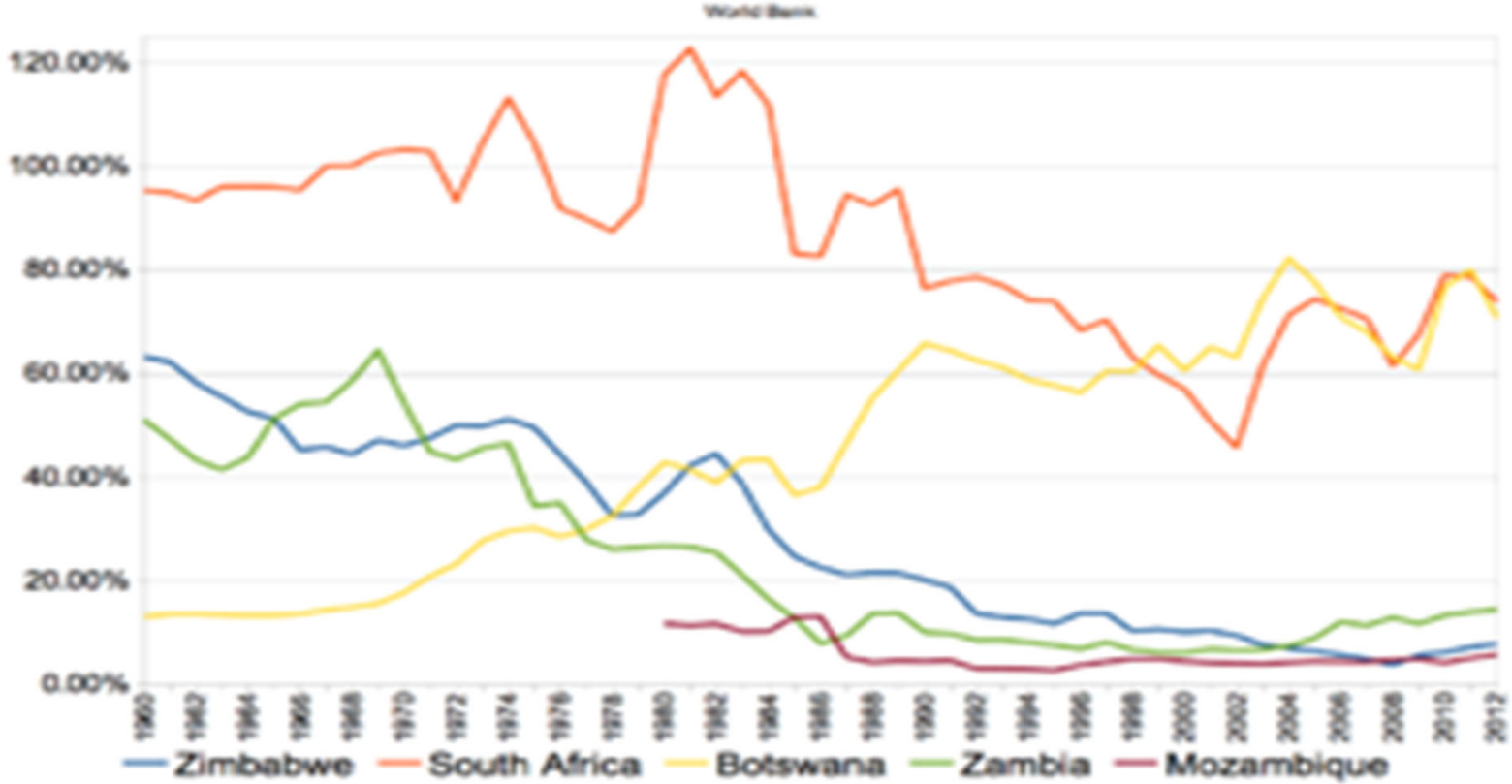

Source: Nangombe (2013)

Figure 1 shows the economic inequality existing between countries in Southern Africa which are Zimbabwe, South Africa, Botswana and Mozambique. Whilst Zimbabwe's GDP used to be among the best, it shrunk considerably by 2012. GDPs of South Africa and Botswana were the best by 2012 whilst those of Zimbabwe, Zambia and Mozambique were very low. From the figure, Zimbabwe was second from the last with its GDP at around 8 percent by 2012 whilst Botswana and South Africa were the best. This economic inequality goes a very long way into explaining why Zimbabweans have been favouring migrating to South Africa and Botswana where economic conditions are more favourable as the GDPs of these countries were around 80 percent as at 2012.

Table 2: Economic situation in Zimbabwe since 1990

\begin{tabular}{|l|l|}
\hline Year & Economic situation driving migration \\
\hline 1990 & ESAP \\
\hline 1992 & Drought \\
\hline 1994 & Drought \\
\hline $1997-8$ & Appeasement policy towards war veterans, military intervention in the DRC war \\
\hline 2000 & Fast Track Land reform Programme, \\
\hline $2004-5$ & Operation Murambatsvina, Parliamentary elections \\
\hline 2008 & Outbreak of cholera, Violent elections and repression, hyper inflation \\
\hline 2010 & Multi currency system \\
\hline 2014 & Indigenisation, Unemployment \\
\hline 2016 & Cash shortages, underpayment of workers, Late or no payment of workers \\
\hline
\end{tabular}

Sources: Nicola de Jagger and Musuva 2015

Table 2 explains the economic conditions in Zimbabwe from 1990 to 2015 which led to economic inequality and economic disparities between Zimbabwe and other countries, particularly countries in southern Africa. The table shows that there have been a multiple of factors which have led to a slow but gradual collapse in the economy 
of Zimbabwe. This has generally resulted in the mass exodus of workers in Zimbabwe to other countries in which there are stable economies.

Table 3: Number of Zimbabwean Migrant Workers in South Africa and Botswana from 1990 to 2016

\begin{tabular}{|l|l|l|}
\hline Period & Workers in South Africa & Workers in Botswana \\
\hline 1990 to 2000 & 133 & 98 \\
\hline 2000 to 2010 & 15,628 & 12,300 \\
\hline 2010 to 2016 & 1200000 & 100000 \\
\hline
\end{tabular}

Sources: Nicola de Jagger and Musuva 2015, Betts \& Kaytaz 2009, Statistics South Africa, documented migration, 2011, 2012, 2013

Table 3 shows the number of migrant workers in South Africa and Botswana since 1990 to 2016. These neighbouring countries to Zimbabwe are believed to offer better wages and salaries for the same jobs back in Zimbabwe and it has been noted that these countries have been performing very well in as far as their economies are concerned with Botswana basing on the diamond and being one of the fastest-growing economies in the world and its economy dominated by mining, cattle and tourism. Botswana's GDP per capita is estimated to be around $\$ 18,825$ per year as of 2015 , which is one of the highest in Africa (The C. I. A 2014). According to the ILO (1998:22-23) Zimbabweans migrate to South Africa because South Africa's GDP is ten times than that of all SADC countries combined hence there are a lot of opportunities. Also, South Africa's income level is above the US\$500 mark when compared to that of other SADC countries, which acts as an incentive. The South African economy is seen to have the capacity to absorb its own population and labour migrants in Africa and even when the labour market is saturated with unemployment, foreigners are able to get jobs because there are employers who prefer them as a source of cheap labour (Ngomane 2008)

3.1.2 Environment: Climate change and Drought

Agriculture in Zimbabwe has been noted to contribute to $19 \%$ of the country's GDP. It has also been acknowledged that $80 \%$ of Zimbabweans depend on this agriculture, which mostly rain is fed, for their livelihoods (Madzwamuse, 2010). Historically, Zimbabwe was a major food exporter. The country recorded surpluses in food production almost every year. However, in recent years, crop production in the nation largely declined. One of the main contributing factors of this can be attributed to erratic and sub-normal rainfall amounts. Over the past decade, the country has been receiving an amount of rainfall which has deviated from the multi-decadal mean on a regular basis (UNEP, 2010). It has also been recorded that on the later part of the 20th century, runoff in the country fell by 20 to $30 \%$ (MMET, 1998).

According to Nangombe (2013), recently, droughts have been crippling Zimbabwe and have largely contributed to low life-expectancy levels and high levels of emigration. This is evident from the drought of the $1991 / 1992$ season, for example. In these years, maize production decreased by almost 75 percent and this left a large percentage of the population in dire need of food aid (Nangombe 2013). The Grain Marketing Board (GMB) domestic maize intake during the 1992 drought year was about 13000 tonnes - just enough for two days consumption for the nation (ibid). In terms of livestock, over one million head of cattle are believed to have died of starvation during the year. The other years in which drought occurred in Zimbabwe were the 1993 and 1994 2002, 2004 and 2012 seasons and in these years, livelihoods were also affected (ibid). The 2012 drought is believed to have seen a deficit of about 45 per cent in the nation's staple food source, maize, (FDI Global Food and Water Security Research Programme, 2012). As such, about 1.4 million Zimbabweans faced famine in 2012 (FDI Global Food and Water Security Research Programme, 2012). Therefore, these cumulative drought occurrences in rural Zimbabwe since 2002 have culminated in the stagnation of rural livelihoods which were largely agro-based. This deliberation has not only entrenched rural poverty, but, has seen the perpetuation of migration by Zimbabweans to other countries where they feel there is food security (ibid).

Table 4: Droughts in Zimbabwe from 1990 to 2013

\begin{tabular}{|l|l|l|l|}
\hline Grade & Extreme Drought & Severe Drought & Mild Drought \\
\hline Drought years & 1992 & 2004 & $\begin{array}{l}1991 \\
209522002 \\
\end{array}$ \\
& & & 20003200822009 \\
\hline Total number since 1990 & 1 & 1 & 9 \\
\hline
\end{tabular}

Source: Nangombe (2013)

Table 4 shows the number of years in which droughts occurred in Zimbabwe. These are grouped into extreme drought, mild drought and severe drought. Inasmuch as extreme droughts and severe droughts occurred only once since 1990, it must be noted that there has been an increasing occurrence of droughts in Zimbabwe since 1990. Even though some these droughts were mild, they still had an impact on the livelihoods of Zimbabwean citizens, which therefore exacerbated international migration. According to the table, there are a total of eleven droughts which occurred in Zimbabwe since 1990, and this looks very bad as it co notates that in all these years, international migration was prevalent.

According to Zimbabwe News by Andrew Mambondiyani on 6 November 2013, although there are other 
reasons forcing Zimbabweans to migrate, the United Nations Environment Programme (UNEP) reported that it was now recognizing environmental degradation and climate change as major drivers in both forced and voluntary international migration in Zimbabwe.

Climate change was noted to threaten to cause one of the biggest refugee crises. Climate change experts have even warned that up to 200 million people may be forced to abandon their homes over the course of the century the world over if nothing is done about climate change. As such, it has always been accepted that most of the Zimbabwean migrants are driven by political and economic conditions but the truth is that climate change has also been contributing towards this mass migration in its own way (ibid). Crops are failing, livestock are dying and clean water is becoming scarce, forcing many people to abandon their traditional homes (ibid).

In support of the above sentiments, The Zimbabwean of 29th September 2016 reported of Murombedzi a farmer aged 30 who noted that:

'I was a farmer in Zimbabwe but the climate conditions have become unpredictable. It is now difficult to have a good rain-fed cropping season. I used to have more than 20 heads of cattle but lost 15 beasts due to drought. I came here (South Africa) in 2010 and am doing menial jobs on the local farms. It is better than watching my cattle dying back home. Yes some people are running away from (President Robert) Mugabe's iron-fist rule but I am not one of those people. I am running away from drought and hunger."

A Zimbabwean climate change journalist residing in South Africa, Fidelis Zvomuya, added that farmers in Zimbabwe were no longer employing many workers like they did before, the major reason being persistent droughts, resulting in people crossing borders to look for employment in neighbouring countries. He also added: "The lack of food in areas like Matabeleland provinces in Zimbabwe where droughts are now an annual event is forcing people to cross to South Africa for jobs"

3.1.3 Globalisation

According to Held et al (1999), globalisation can best be defined as the 'widening, deepening and speeding up of worldwide interconnectedness in all aspects of contemporary social life.'

The common assumption is that technological change has facilitated migration around the world, not sparing Zimbabwe. In geographical pathways this is threefold. It can be noted that technological change has lowered resource constraints on mobility by bringing down costs of travel and communication. As such, a lot of Zimbabweans are finding it very easy to travel abroad because there are fewer constraints.

Secondly, through globalisation, migrant networks and transnational ties have been strengthened, hence making it easier to stay in touch with family and friends, to remit money and to travel back and forth between destination and origin countries (Faist 2000; Vertovec 2004; Vertovec 2001). A study carried out by Zanamwe and Dellivard (2008) noted that a lot of Zimbabweans have relatives living abroad. Through globalisation, Zimbabweans who are back home can easily communicate with their relatives abroad who can then facilitate for migration of their relatives. The norm in Zimbabwe is therefore that if one has a close relative abroad, the chances of not going abroad also are next to zero.

Thirdly, due to increased literacy and education together with improved access to 'global' information through (satellite) television, mobile phones and internet, people's aspirations and awareness to travel to previously unknown countries have increased. According to de Haas (2009), these processes seem to have increased people's capabilities and aspirations to migrate and this is the case, particularly with some Zimbabweans who migrate.

\subsection{Proximate factors for migration in Zimbabwe}

According to Wikipedia, a proximate cause is a cause which is immediately responsible for causing something observed. According to van Hear et al (2000), in countries and regions of origin, proximate factors include such manifestations as a downturn in a business cycle, human rights violations, environments infested with power struggles, development projects that involve displacement, or marked environmental degeneration, including the effects of climate change. In places of destination, proximate factors may include opportunities that open up as a result of economic upturn, wider societal improvement like new employment opportunities, the chance start a business or to engage in trade, or taking advantage of new educational openings.

3.2.1 Religious duties

A common cause for migration in Zimbabwe is the fulfilment of religious duties. Hundreds of Zimbabweans have been flocking to other countries as pastors; hence religious duties may also be another major driver of migration. An example of a church which has been sending hundreds of pastors abroad is ZAOGA. Being one of the largest Pentecostal churches in Zimbabwe, it is known to be well established in over 104 countries which include the UK, USA, Australia, Ukraine, Malaysia and China as well as neighbouring Southern African countries. In the various geographical locations where ZAOGA, known abroad as Forward in Faith has flourished, Zimbabwean pastors have been sent to fend for the Zimbabwean believers in those countries, thereby raising emigration numbers in Zimbabwe. We conducted a telephone interview with one of the 30 diaspora informants from the U.K who is a Zimbabwean pastor from ZAOGA, Pastor G. Gwerete. Upon asking how and why he migrated to the U. K, he said, 
"I left Zimbabwe because I was sent by the church to administer my pastoral duties here in Casterbridge and I had to leave together with my family and settle permanently here. I am not the only one but there are several of my friends who were also sent here in the U.K to administer the same duties. I know of my friend who was sent to F.I.F Kent and the other one is at the F.I.F church in London,

3.2.2 Loss of land or houses

According to Potts (2007) in 2005 the government of Zimbabwe embarked on a destructive campaign which was against informal housing and employment in towns. This resulted in massive movements within cities and out of the country. Barrister (2007) also noted that Operation Murambatsvina was simply a very violent process which resulted in the displacement of hundreds of thousands of people, destruction of businesses, property and houses. There was also widespread loss of livelihoods and the injury and deaths of some residents. The destruction of the informal business sector and shanty towns around many urban areas resulted in joblessness, homelessness and internal as well as external migration.

According to a research carried out by the University Of Zimbabwe Department Of Sociology (2005) in Hatcliffe Extension, the destruction which was caused by the Murambatsvina left most people with nothing at all and these people decided to migrate illegally to South Africa because they had virtually nothing else to stay for. The Hatcliffe residents in the survey reported that they lost household physical property such as wardrobes, beds, fridges, radios and solar panels which were either damaged by bulldozers and army vehicles, or destroyed in the fire in the pandemonium that the clean up exercise was. These people lost even their pots, pans and market stalls. As such, assets which they had acquired over long periods of time of hard labour suddenly vanished from their grip, with disastrous consequences on their livelihood security and this pushed them to migrate either to the rural areas or to be illegal immigrates in nearby countries (ibid). One of the interviewees in the survey remarked,

'I was away in the rural area. When I came back, I couldn't recover even a teaspoon. I also lost my passport, my children's birth certificates and my professional certificates in the fire. Now I can't even get employed by anyone so I am thinking of crossing the border illegally to South Africa. Maybe I can get piece jobs which can help me there since I have nothing at all here. '(Ben Mutanga 23) (University of Zimbabwe Department of Sociology 2005).

\subsection{Precipitating factors for the migration of Zimbabweans}

Precipitating factors can be defined as those factors that actually trigger departure. In this arena, individual and household decisions to move or stay put are made. According to van Hear et al (2012), these precipitating factors may economic factors such as financial collapse, unemployment, industry closure, a collapse in wages, the imposition of punitive taxation, or the disintegration of health, education or other welfare services. They may also be political, including persecution, disputed citizenship, the exacerbation of conflict, massacre, outbreak of war, or invasion.

3.3.1 Economic hardship

'You who is leaving the country today, where do you really stand? You are fleeing your country for England. Who knows you there? To become a servant in another country! Now you are being herded like cattle back to this country..." (Robert Mugabe, August 2006).

"We now leave in separation with our beloved because of poverty" (Respondent, 2005) (Tevera and Crush 2008).

Over the past two decades, declining economic conditions have been a leading cause of migration from Zimbabwe (Tevera and Crush 2008). According to Chikanda (2011), these economic problems began with the introduction of the IMF/World Bank led Economic Structural Adjustment Programme (ESAP) in 1991. Due to economic mismanagement, these problems worsened considerably with the chaotic land reform programme as well as the violence that marred the 2000 elections. Due to the destruction of the productive agricultural sector, Zimbabwe was reduced from being a food exporter into a food importer. This affected the downstream industries which depended on agriculture. This led to the soaring of inflation. In 2008, inflation peaked at 231 million percent (Hanke 2008). 
Figure 2: Zimbabwe's G.D.P annual rate 1963 to 2008

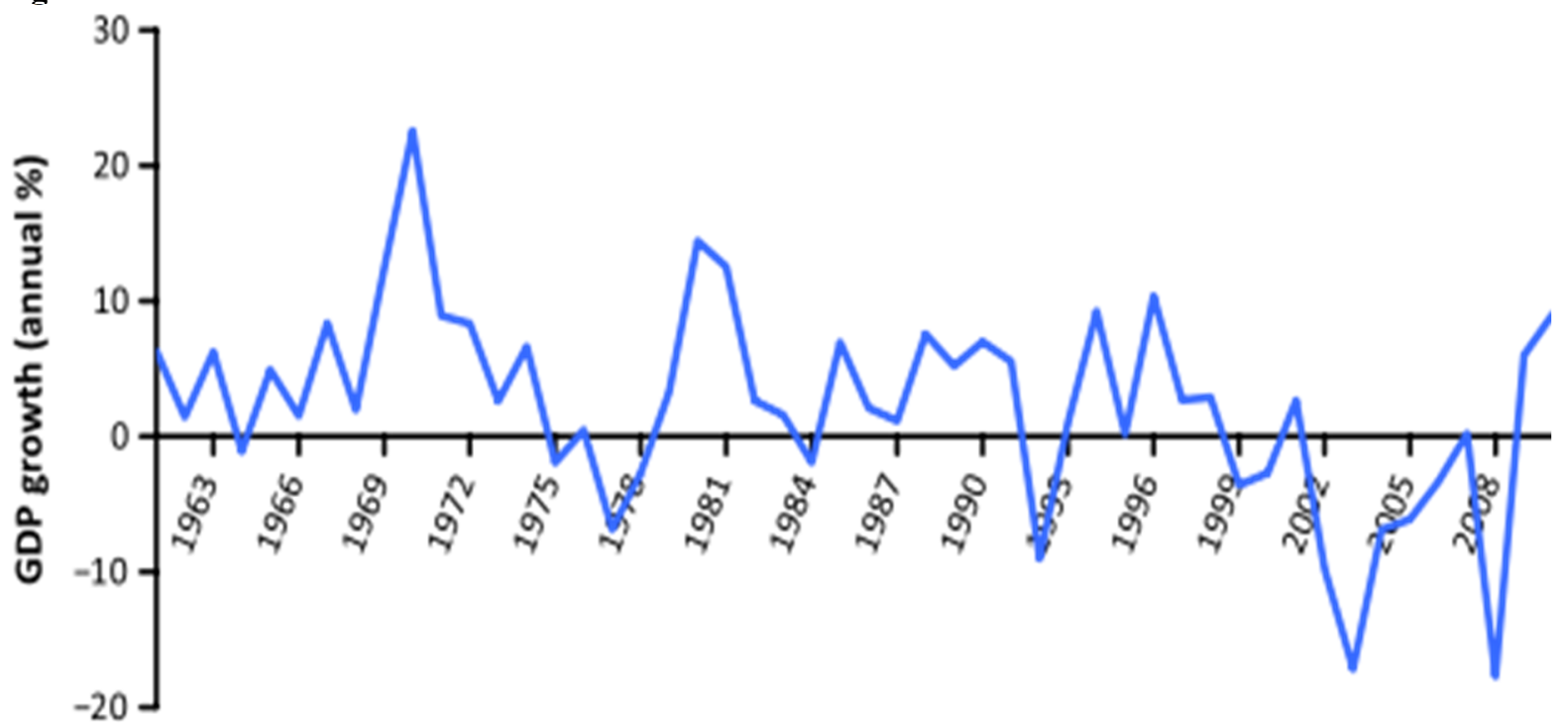

Source: Nangombe (2004)

Figure 2 shows Zimbabwe's Gross Domestic Product annual rate as from 1963 to 2008. The table reflects that Zimbabwe's GDP was on upward trend since 1963 but as the years went on, it shrank pathetically to -20 by 2008. This clearly shows how hard economic conditions have become in Zimbabwe. The years 1963 to 1975 were good years as the GDP of Zimbabwe was well above half. It shrank a bit from 1975 to 1978 but significantly rose to favourable standards from 1978 to 1984 . Thereafter, it was on an upward trend till 2002 when it fell. From 2002 to 2008 , the GDP continued to fall down to the lowest standards of -20 and it seems there is no hope for the redeeming of the Zimbabwean GDP ever since.

According to Chikanda (2011), economic conditions were the primary reasons cited by medical emigrants for leaving the country from 2000. Chikanda noted that while $71 \%$ of his respondents agreed that bad economic conditions were a major factor in prompting them to leave before 2000 , the figure rose to $95 \%$ of those who left after the year 2000. One of his interviewees, Dr Mary Chikomo, who left Zimbabwe in 2003, reiterated: By the end of 2002 things were really tough. It was tough in the sense that the salary was not enough to buy what we needed. It was worsened by the fact that we could not get most of the basic commodities in the shops and to get them you had to spend a lot of time queuing up. So we had to queue up to get things like maize meal. That was a great inconvenience to me.' (Chikanda 2011)

Sour economic conditions continue to influence the departure of both skilled and unskilled Zimbabweans to this day. Whilst the 2009 power-sharing agreement between the ruling ZANU PF and the opposition MDC(T) went a long way towards restoring economic stability and the rate of inflation dropped with the introduction of the US Dollar, the salaries of most workers remained low and this has motivated more and more Zimbabweans to migrate. With the 2013 presidential elections and the regaining of power by President Robert Mugabe, more and more economic downturns have erupted, chief among these downturns being the issue of cash shortages which has seen the potential introduction of the controversial bond note which is believed to worsen economic conditions if it is introduced.

Of the 30 informants in the diaspora whom I interviewed, 19 were of the view that they migrated from Zimbabwe because of sour economic conditions, 8 pointed out political instability, other 2 pointed out loss of land whilst 1 mentioned religious duties. This indicates the fact that economic hardship is the major precipitating driver of migration in Zimbabwe.

It also turns out that most Zimbabweans are living in fear of the introduction of bond notes as from January 2016 with hundreds of Zimbabweans migrating before its introduction to avoid suffering. Of the Zimbabwean professionals whom I interviewed, one teacher, Mrs Angeline Vurasha a Business Studies teacher, gave the following answer,

'I do not think I will stay in Zimbabwe to witness the coming of the era of the bond note. I think its introduction is bad news to this country. As soon as the government announces that the bond note is out, I will make connections with my relatives in the diaspora and get out of this country because I cannot stand to relive the year 2008 where there were no basic commodities and uttermost suffering again.'

3.3.2 Unemployment

The CSO (2006), refers to unemployment as the population age of 15 years and above who did not work and had no job or business to go back to during the seven day reference period, but who were available for work. By this definition, it appears that there is no unemployment in Zimbabwe because there may not be people actively looking 
for work. This is because there are no places to look for the work. Most of the industries and workplaces have long shut down and the few available industries, including jobs in government, pay very little salaries that none of the informally employed would even want to secure these jobs. According to Dodo and Dodo (2014), in Zimbabwe, an average graduate selling talk-time in street earns an average of US $\$ 20-28$ a day (US\$868/month) compared to US $\$ 480 /$ month remuneration paid by the government and most factories.

There is, therefore, little doubt that Zimbabwe faces a problem of inescapable unemployment especially amongst the youth (ibid). The Zimbabwean government officially argues that unemployment rate staggers between $15 \%$ and $17 \%$ because most of the people are, somehow, engaged in some sort of work which pays when the day ends. However, this argument does not consider the factors which include: levels of education, level of income vis-a-vis the nature of work and also whether the type of work is taxable or not (Dodo and Dodo 2012). According to ILO (2006), the general unemployment in Zimbabwe stands at over 85\%, with youth unemployment standing at over $70 \%$. Because unemployment rates are so high, Zimbabweans are fleeing to countries where they can get employment.

According to The Zimbabwean (31 January 2016), a survey by Dr Prudence Magejo and Professor Miracle Benhura came out with the findings that about 10000 documented Zimbabwean professional lived in South Africa in 2001. And from that sample, most of the migrants had generally come to South Africa to look for work. Benhura was once a PhD holder who also fled Zimbabwe in search of work. He had this to say,

'Zimbabwe was already in a crisis when I finished my PhD in 2007, which pushed me to consider job offers in South Africa," (The Zimbabwean 31 January 2016).

A survey by ZimEye.com's correspondent in Johannesburg South Africa also provided the same statistics when the correspondent highlighted that there were a lot of Zimbabweans on South African streets who fled from Zimbabwe in search of work but could not secure employment also in South Africa. A Zimbabwean by the name Bernard Mpofu, a qualified diesel plant fitter who graduated from Harare polytechnic, who left Zimbabwe to look for employment in South Africa was interviewed. Upon being asked by the correspondent whether he would want to go back home as employment was also hard to come by in South Africa, Mpofu uttered the following sentiments: "I will never go back to Zimbabwe. I would rather suffer here doing piece jobs and hope to get a job one day than go back to Zimbabwe where there is no hope that one day I will get a job” (Zim Eye News 28 July 2015)

I conducted Focus Group Discussions with four groups of respondents who either waited to be interviewed to get visas or were lodging visa applications at four different embassies in Zimbabwe (Canadian, U.S, U.K and SA. embassies). At the Canadian embassy, there was a group of 5 respondents. Two of these said they wanted to leave the country because of economic hardships, despite the fact that they were employed, while the other three said they wanted to seek for employment in Canada because Zimbabwe had failed them in this area. At the U.S embassy, there was a group of 7 respondents and 4 of the respondents pointed out that they wanted to leave because of economic hardship; 2 said they were going to seek for employment in U.S.A whilst the other one respondent said he wanted to leave because of political insecurity. At the U.K embassy, there was a group of 6 respondents. Of these 6 respondents, 4 said they had Degrees but had failed to secure employment in Zimbabwe therefore they wanted to seek for employment in the U.K whilst 2 of them said they were leaving because economic conditions in Zimbabwe had become dim. All the respondents who were interviewed at the South African Embassy cited that they wanted work permits to go and seek employment in South Africa. This data shows that high unemployment rates in Zimbabwe are mainly facilitating for emigration from the country.

3.3.3 Disintegration of health and education services

After independence, efforts were made by the new Mugabe led regime to ensure that health care institutions were established even in disadvantaged areas (Chikanda 2013). These gains were eroded by the economic collapse after 2000. In a survey carried out by Chikanda (2013), 52\% of the respondents which he surveyed reported that due to the collapse of the health care system they decided to leave the country. According to Chikanda (2013), there was shortage of drugs, medical equipment and qualified medical personnel as of 2008 which prompted most Zimbabweans to leave the country. This was exacerbated by the growing HIV and AIDS crisis which increased the demand for healthcare services. In 2008, there was widespread scarcity of drugs and medicines and a number of hospitals stopped working. The country's large central hospitals dismissed sick patients, leaving only the emergency sections open (ibid. Some of the problems in the health care system were attributed by the doctors to poor managers without a medical background: According to Chikanda (2013), one interviewee mentioned:

"There was a lot of interference from non-medical people who would just come and give you instructions on how to treat people. Sometimes, you would find someone being admitted just for social reasons in place of the deserving sick patients because there is no one to speak for them. So we had very little clinical and medical independence. So for me that was my biggest trigger to leave the country."

In the education sector, Zimbabwe was once second best to Tunisia in Africa but these standards have since deteriorated and this has led many to migrate in a bid to attain better education standards for their families. Standards deteriorated since the establishment of the ZIMSEC after 2002. This is mainly because after the establishment of ZIMSEC, the system became characterized with corruption, fraud and shoddy work to an extent 
that certificates have been finding means to people who would not have written examinations (Dodo and Dodo 2014). As such, from 2007 to 2009, ZIMSEC is said to have failed to administer examinations because over 8000 schools had closed due to an economic crisis (Dodo et al, 2014). Also, over 90000 teachers were not going to work and textbook to pupil ratios had fallen to an average of around 1:15 (ibid). According to Coltart (2012), in the entire Education ministry, during the time of the economic crisis, there were no operational Education Management and Information Systems (EMIS) and no correct statistics since 2006 (ibid). Because of this, the industry and most tertiary institutions have been refusing to recognize schools' graduates who were produced during this era and this his has seriously affected the quality of the Zimbabwean education system, and has immensely contributed to migration of Zimbabweans in search of better education facilities.

More and more have left the country to attain higher education from countries which they think can offer better and reliable diplomas and degrees. The education sector is being handled with more and more confusion such that most Zimbabweans see no hope for the education of their children. This is evident from the new controversial curriculum to be implemented from 2017. From interviews I conducted with professionals in Zimbabwe, most of them were considering sending their children to schools outside of the country if this curriculum went through. One teacher even said:

'I see no way out of this hopeless situation but to send my children to schools abroad. I would rather have my children have quality education than stay here to recite the national pledge and learn Heritage Studies at the expense of proper History which we learnt in our time'

3.3.4 Political insecurity

Elections in Zimbabwe have been regular, free but unfair as they have been characterised by violence and human rights violations. This has resulted in most Zimbabweans being politically insecure. Since 2000 there have been constant reports of persecution of most Zimbabweans during elections. This has seen the massive migration out of Zimbabwe in the past two decades. Dick Ranga (2014), debated on the role which was played by the political crisis in Zimbabwe in encouraging teacher migration to South Africa when there were also other social and economic drivers.

Ranga collected data through in-depth interviews with a few migrant teachers in South Africa after the 2008 elections. According to the data which he came up with, political insecurity was the second most mentioned reason for the teachers' migration to South Africa. As such, most migrant teachers in South Africa came from Zimbabwean schools which were affected by political violence before or after the 2008 presidential elections, especially in rural areas. This was because teachers who held positions in the opposition party or distributed opposition party regalia were found to be the highest percentage of Zimbabweans who had been displaced by violence, hence showing the extent to which political instability in Zimbabwe has driven international migration.

According to a research carried out by Enigbokan et al (2013) on Zimbabweans living in South Africa, all Zimbabwean migrants pointed to the existing political situation in Zimbabwe as a push factor which motivated their decision to move to South Africa. One of the respondents mentioned that he left Zimbabwe in 2007 in view of the political situation in Zimbabwe in order to pursue a career and have a better chance in life. Another of the respondents in Enigbokan's research pointed out that the political instability of 2001 led to feelings of insecurity for females in Zimbabwe and this motivated her to leave the country for South Africa. She stated that:

"Physical attacks were taking place in Zimbabwe at the time, especially against girls in my area during the elections rally in 2001; my mother wanted me to leave the country for my own safety as a female".

As of 2016, there have been demonstrations in the "Mugabe Must Go" campaigns which have resulted in civil unrest, especially in the capital city of Zimbabwe, Harare. These campaigns have been witnessing brutal attacks of Zimbabweans by the Zimbabwean police and the army. Some fellow Zimbabweans claim that their rights are being grossly violated by the army, which has prompted most of the Zimbabweans to live in constant fear whilst some are considering leaving the country in search of peace and security.

According to Internet TV News by Patricia Mudadigwa on 26 August 2016, Pastor Evan Mawarire, the man who is responsible for the commencing of these demonstrations, started his movement when he posted a video online a few days after Zimbabwe celebrated independence. In this video, Mawarire said he was prompted by his failure to raise school fees for his children to use the national flag to question what is going on in the country. He was then arrested by the police after the July $6^{\text {th }}$ protests which led to a complete shutdown of Zimbabwe. Charges which were laid against him of attempting to subvert a constitutionally-elected government were dropped by a Harare magistrate but he decided to leave the country a few days after the court case, indicating that his life was in danger (ibid). It is said that he is now settled in the United States of America.

According to Nehanda Radio News (July 20 2016), President Robert Gabriel Mugabe uttered the sentiments that Mawarire was supposed to move to another country if he was unhappy with conditions at home. According to Internet TV News by Edinah Masanga (1 August 2016):

'Mawarire is justified in seeking for an asylum in the U.S.A because he has an obligation to keep his family safe. This is so because a lot of opposers to the Mugabe regime such as Learnmore Jongwe, Solomon Mujuru and Rex Nhongo all died under unexplained circumstances. Also, Itai Dzamara and Rashiwe Guzha disappeared after 
calling for Mugabe to step down'

3.4 Mediating factors for migration from Zimbabwe

Mediating factors may be referred to as the psychological and social conditions in the communication process which moderate the effects of mass communication (Donsbach 2008). According to Van Hear et al (2012), mediating factors can facilitate for migration. Facilitating factors may include the presence and quality of transport, communications, information and resources needed for the journey. In this research the mediating factors which are most imminent in Zimbabwe are the presence of recruitment agents and the presence of illegal visa trading, which all facilitate for international migration in the country.

3.4.1 Presence of recruitment agents.

There are recruitment agents from other countries who are also playing a vital part in catering for the emigration of skilled Zimbabwean workers. The Namibian government has been playing a vital role in recruiting teachers from other SADC countries mainly Zimbabwe, Botswana, Kenya, South Africa and Zambia to boost their education system. This has seen a lot of Zimbabweans flocking to Namibia because of the facilitation role of their government.

There are various recruitment agencies in Zimbabwe such as the Valcol Group which offers great career opportunities to multilingual professionals in Zimbabwe. It also works with well renowned multinationals and recruit personnel for directorship, executive, managerial and support roles in Zimbabwe and regionally. Another recruitment agency in Zimbabwe is Aerotek, which is a leading staffing agency which matches qualified candidates with top companies worldwide. Also, iPlace is another recruitment agency providing recruiting services to US Firms from Zimbabwe. It is a global recruiting company headquartered in McLean. Due to the presence of these recruitment agencies, a lot of Zimbabweans are finding their way to various countries which these recruitment agencies take them.

\subsubsection{Presence of illegal visa trading}

Because of all these difficult conditions in Zimbabwe which range from political, economic, and social hardships, Zimbabweans have deviced ways and means through which they can flee the country. Illegal visa traders have emerged who neccessiate for migration to those with the funds to migrate. These traders have knowledge on various destination countries and even have links with diasporian communities in those countries. They know about the emigration policies in those countries and generally how long it can take for a asylum seeker to have an asylum in any given country. These visa traders even have links with various personnel on various border posts and assist their clients on what to do or say when they reach their destinations. This has made it quite easy for those Zimbabweans with the money to migrate to other countries where they can seek for asylums once they get there.

From the diaspora informants whom were interviewed, we managed to make connections with two illegal visa traders in Zimbabwe. We then held an interview with these illegal visa traders and one of them had this to say,

'We are in a business to facilitate for the granting of visas to anyone who is willing and with money. We have managed to send people to different countries such as Canada, United States of America and Germany. What we do is link anyone who desires to move to these destinations with a specific job such as nursing or with a Non Governmental Organisation such as Doctors without Borders. Our client is able to move to these countries with no problems at all. If a whole family wants to leave, we can facilitate for that as well and our visas cost around $\$ 1,500$ per person.'

\section{Discussion and Conclusion}

Various drivers of migration were indicated in this paper. These were grouped into four parts namely predisposing factors, proximate factors, precipitating factors and mediating factors. Under the predisposing factors, the following factors came out: regional economic inequality, globalisation and drought/climate change in Zimbabwe which facilitates migration. Under the proximate factors driving migration in Zimbabwe, the following factors have been indicated: religious duties and loss of land or houses. Under the precipitating factors, economic hardship, unemployment and political insecurity were indicated. Under the mediating factors: presence of recruitment agencies and illegal visa trading were highlighted. Interviews with informants in the diaspora and desk literature review enabled the researcher to come up with sufficient data to support these factors. Having noted the above factors, it may be plausible for policy makers to seek to make adjustments and find solutions to the problems indicated herein so as to cultivate benefits from international migration.

\section{References}

List of textbooks used

- Barrister, M. 2007.Operation Murambatsvina; A Crime against Humanity. London: Oxford University Press. 
- $\quad$ Dodo And Dodo (2014): Unemployment And Conflict In Zimbabwe: An Analysis And Resolution

- Faist, Thomas. 2000. The Volumes and Dynamics of International Migration and Tra Madzwamuse, M. (2010). Climate Governments in Africa: adaptation strategies and institutions. A synthesis report prepared for the Heinrich Boll Foundation. Ministry of Mines, Environment and Tourism (MMET) (1998). Zimbabwe's Initial National Communication on Climate Change under the UNFCC.

- Nangombe (2013): Drought conditions and management strategies in Zimbabwe, Meteorological Services Department, Harare, Zimbabwe

- $\quad$ Nicholas Van Hear, Oliver Bakewell and Katy Long (University of Oxford) 2012Migrating out of Poverty Arts B, University of Sussex Falmer, Brighton BN1 9QN, United Kingdom

- Tevera and J. Crush, The New Brain Drain from Zimbabwe. SAMP Migration Policy Series No. 29, Cape Town, 2003; A. Bloch, "Emigration from Zimbabwe: Migrant Perspectives" Social Policy and Administration 40(1) (2006): 67-87; J. McGregor, “Children and 'African values': Zimbabwean Professionals in Britain Reconfiguring Family Life" Environment and Planning A 40 (2008): 596 - 614.

- Vertovec, Steven. 2001. "Transnationalism and Identity." Journal of Ethnic and Migration Studies 27(4):573-82. —. 2007. "Super-diversity and its implications." Ethnic and Racial Studies 30(6):1024-54.

\section{List of articles used}

- Chikanda Series Editor: Prof. Jonathan Crush Southern African Migration Programme (SAMP)2011

- De Haas, Hein. 2009a. "Migration and human development." International Migration Institute Working Paper no. 14. University of Oxford.

- Steffes, Tracy (2005), "Zimbabweans", In Reiff, Janice L.; Keating, Ann Durkin; Grossman, James, Electronic Encyclopaedia Of Chicago, Chicago Historical Society, Archived From The Original On August 29, 2008, Retrieved 2009-04-18

\section{List of Newspapers, Reports and Magazines used}

- $\quad$ Nehanda Radio News (July 20 2016)

- $\quad$ The Zimbabwean 31 January 2016 